\title{
International Cooperation to Combat Money Laundering in the Southeast Asia: A Narrative Perspective in Vietnam
}

\author{
Huyen Quang Tran \\ People's Police College I, Thanh Xuan District, Hanoi 100000, Vietnam
}

\begin{abstract}
The fight against money laundering is a special concern of international, regional, and national scale. In recent years, Vietnam is a country that is significantly affected by this type of crime. To combat money laundering need not only to strengthen domestic legislation's system and professional task forces, but also to enhance international cooperation among multilateral and bilateral agreements between host countries and their counterparts. Using the document analysis combined with legal norm's analysis, this paper draws the nature of money laundering in Vietnam and also analysis Vietnam's perspectives to implement their national efforts to curb this crime. The research highlights the significant role of international cooperation in this battle rather than building national improvements. Some recommendations to improve the effectiveness of international cooperation to fight money laundering in general as well as to enhance policing plans of Vietnam's law enforcement agencies that call for special attentions in the end of the research.
\end{abstract}

Keywords: Money laundering, money laundering prevention, international cooperation, Vietnam

DOI: $10.7176 / \mathrm{JLPG} / 96-09$

Publication date: April $30^{\text {th }} 2020$

\section{Introduction}

Money laundering is becoming a concern of many countries in the world, it directly affects most countries, causing negative effects on the macro economy in general and the financial sector country. The leading experts in the money laundering's project of the United Nations on Drugs and Crime (UNODC, 2020) estimates that the average annual amount of money put into the washing cycle accounts for $2-5 \%$ of the total income of the world economy, or US\$800 billion-US\$2 trillion per year. More seriously dangerous impacts is that development of money laundering activities will also promote a series of other crimes such as drug trafficking, arms trade, corruption and terrorism crimes (Shehu, 2000; Williams, 2001). In particular, for emerging markets in both low and middleincome countries in the Asia, the opening of the economy and the financial sector will make them targets of money laundering activities, no except for Vietnam (Global Financial Integrity, 2017, 2019). This is not only a matter of a nation but also a concern of all humanity and therefore, the fight against money laundering is a global mission. In other words, anti-money laundering is becoming an issue that is being concerned by countries around the world and starting the cooperation process in the prevention and combat of money laundering acts.

Through methods of document research, comparative analysis and legislative regulation in Vietnam, this paper is to focus on assess Vietnam's approach and implementing to international cooperation to prevent and combat money laundering. Particularly, the paper presents Vietnam's strategies and plans to enhance cooperation to fight money laundering within the scopes and conditions of both international and regional scale. From which to make judgments, recommendations and recommendations suitable to promptly meet the requirements of the fight against money laundering in the new situation that also call for special attentions for government, stakeholders, and policymakers in Vietnam. One overview of the picture of international cooperation's efforts to combat money laundering will be introduced firstly as bellow section.

\section{International cooperation against money laundering: An Overall Context}

According to the most common interpretation, money laundering is the act of transferring the profits earned from illegal activities to legal profits (Levi, 2002; Reuter \& Truman, 2004). Money launderers often transfer money interwoven with legal sources of money and switch between business activities with many different accounts, or between domestic accounts and foreign accounts (Lilley, 2003; Reuter \& Truman, 2004). Money laundering has serious socio-economic consequences, affecting national security and reputation, weakening the economy, as well as the process of economic reform (Kubiciel, 2012; Tang \& Ai, 2010). In the face of the harm caused by money laundering, the international community as well as individual countries increasingly recognize the need for comprehensive anti-money laundering programs (Chat, 2014b; Croissant \& Barlow, 2007).

The fight against money laundering has been carried out by countries since the 1970s (Reuter \& Truman, 2004). However, the anti-money laundering measures at this time are mostly limited to administrative and preventive regulations. Offenders have used the open international financial system to profit from free-flowing capital flows worldwide, concealing the illegal sources of criminal proceeds and continuing their activities their illegal (Chat, 2014a, 2014b). Countries around the world have taken bilateral and multilateral cooperation actions in the fight against money laundering. One of the first international organizations set up to limit and prevent this 
type of crime was the Anti-Money Laundering Financial Task Force, also known as FATF in 1989 (FATF, $2010 \mathrm{~b}$ ). It is founded by banks, international financial institutions and leaders of the G7 group and so far, there are 34 member states spread across continents. This is a reputable and practical intergovernmental organization, a pioneer in investigating and preventing money laundering activities, advising countries on measures to combat money laundering which are increasingly raging. In the world, FATF has close cooperation with Interpol - International Criminal Police Organization, and is also responsible for controlling money laundering tips and trends, monitoring domestic and international activities, identifying arising causes and taking measures to prevent (FATF, 2010a, 2010b).

This intergovernmental policy-making organization is responsible for controlling money laundering tips and trends, monitoring domestic and international activities, identifying arising causes and taking measures to prevent currency this accident (FATF, 2010a). Participation in FATF is voluntary, although 40 FATF recommendations for anti-money laundering and counter-financing for terrorism are accepted in the laws of many countries, even many of which have been mandated by a number of international treaties (Chat, 2020; UNODC, 2020). FATF is expanding regional branches to attract more countries to accept its recommendations. Currently, in an effort to create the synchronized power of the international community, the United Nations has a Global Anti-Money Laundering Program (The Global Program for Money Laundering - GPML) based in Belgium. However, the number of countries that are members of this Program is small (UNODC, 2020).

Criminals often launder money through transnational companies and therefore, international cooperation and between countries at different levels in the prevention of money laundering is of particular importance (Chat, 2020; Global Financial Integrity, 2019). Other forms of cooperation may include training support and capacity building; general investigation and its specific techniques; exchanging information and evidence; jointly build and commit to enforce common standards on prevention of money laundering (Chat, 2014a, 2014b). That means, the international cooperation is increasingly necessary at every stage of anti-money laundering investigation (that is, stages of financial intelligence collection, investigation and prosecution). For example, at the stage of collecting financial intelligence for a money laundering, the financial intelligence units (FIU) need to exchange information with their partners abroad to be able to divert properly analyse reports of suspicious activity and other disclosed financial information (Stankiewicz, 2015). It can be said that such things are also necessary for the investigation stage so that the police can successfully investigate the money laundering. The ability to exchange information quickly with foreign partners without any unreasonable obstacles or delays is becoming a staple of any FIU, law enforcements or public agencies (Hutley-Washington, 2018). Currently, anti-money laundering is becoming an issue of countries around the world and starting the cooperation process in the prevention of money laundering, especially through the financial-banking system to prevent criminal organizations from turning nations into places that wash away crime-related properties and money due to their size and harm to the national economy (Kruisbergen, Leukfeldt, Kleemans, \& Roks, 2019). Indeep, the anti-money laundering laws of the countries, the most mentioned issues about international cooperation focus on some key points of either bilateral or multilateral judicial assistance as well as recognition of foreign judgments (Hutley-Washington, 2018; Kruisbergen et al., 2019). However, each country has different provisions on international cooperation in the prevention of money laundering

\section{Money Laundering in Vietnam: An Example of Banking's Risks}

The eighth report of the Global Financial Integrity (2019), based in the United States, recently published a study showing that Vietnam is the highest country among 148 developing countries around the world received illegal money flows from commercial money laundering. This annual report was conducted over 10 years from 2006 to 2015, based on data from the International Monetary Fund (IMF) and the United Nations (UN) that recorded in 2015 alone, Vietnam collected 22.5 billion USD (Global Financial Integrity, 2019). According to Chief Justice Truong Hoa Binh stated that in Vietnam money laundering is not a traditional crime but there are complicated developments and bad effects on the economy in the era of globalization. Reality of preventing and combating crime shows that Vietnam appears quite a lot of very sophisticated methods of money laundering (T.An, 2018). Additionally, money laundering criminals often take advantage of the cash transaction habit to buy high-value assets such as real estate, houses, cars, gold, gemstones which are invested from criminal activities (Lam Giang, 2019; T.An, 2018).

Defined as a criminal offense of money laundering in the Government's Decree No.116/2013/ND-CP of $4^{\text {th }}$ October2013, detailing the implementation of a number of articles of Law on prevention and combat of money laundering. In Vietnam, normally, after committing crimes the offenders often commit acts of self-money laundering due to crimes that exist, the source crimes of money laundering often fall into groups of corruption (e.g. corruption, asset plots, bribes), drug offenses (e.g. illegal trading of narcotics), crimes of infringing upon economic management order (e.g. smuggling, manufacturing, trading counterfeit goods), crimes of infringing upon possessing security and order (e.g. fraud and gambling) (Chat, 2013b, 2014b; T.An, 2018). It can be said that if there is no source crime, there is no money laundering crime. Money laundering is an indispensable result of previous criminal activities with the desire to erase the illegal traces of "dirty" money from criminal activities 
(Lilley, 2003; Reuter \& Truman, 2004). The criminal activities taking place in most countries of the world such as drug trafficking, weapons, corruption, counterfeiting, illegal business, fraud, gambling have brought them back. criminals with big sums, huge fortune (Croissant \& Barlow, 2007; Schneider, 2010). If found, those illicit sums will of course be confiscated and thus, in order to evade the discovery of regulatory agencies, law enforcement agencies, as well as to properly consume those profits, criminals have found ways to legalize the money and property (Hutley-Washington, 2018; Stankiewicz, 2015). As a result, money laundering is not natural, but rather like other behaviors whose nature is due to a criminal act (Borlini, 2014; Schneider, 2008). Therefore, the prevention and combat of money laundering crimes must also come from doing better the prevention and combat of the criminals the source of this crime and also means that when effectively implementing the task of preventing and fighting against money laundering, anti-crime in general will also contribute to preventing and stopping money laundering crime (Croissant \& Barlow, 2007; Tang \& Ai, 2010).

According to State Bank of Vietnam $(2006,2018)$, the stage of money laundering through banking activities could be visualised as follows:

- Stage 1: Bringing illegal money into circulation in the financial and economic system, referred to as "installing" and "sending money". This is the first step of money laundering to convert criminal proceeds into other legal forms and put them into economic and financial cycles. This stage is considered to be the most difficult for criminals because the money and property acquired are illegal and are being monitored by investigating agencies, moreover, the state and agencies have set up many regulations to welcoming criminals of money laundering criminals, such as regulating the amount of cash brought across the border, allowed payment, and regulations on bank declaration. - Stage 2: The process of accumulating and circulating amounts after they have penetrated the financial system, referred to as "shifting", "arranging". In this stage, thousands of operations are performed to make the currency move everywhere, turn around many times to eliminate criminal traces, artificially cut off the link between assets and organizations. Crime. Any country with an open corporate law system is more likely to be taken advantage of through the establishment of a ghost company. In addition, sophisticated financial transactions such as participating in secondary financial markets associated with the use of advanced banking technologies such as Internet Banking also make it difficult for investigations

- Stage 3: Legal investment, referred to as "integration". This is the time when criminals use their money and assets to be cleansed to legally invest in production and business activities in the form of capital for businesses, personal loans, bills, real estate. Then, investment in production and business businesses will increase the value of the currency of crime, mixing legal and illegal currency, this is also a difficult stage. To identify criminal acts. In the recent reports of national assessment on money laundering and terrorism financing between 2012-2017 (Government of Vietnam, 2019), after considering the trends and techniques of money lanudering, proceeds generated by predicate offences and threats of money lanudering abused by sectors, Vietnam recognized that the national money lanudering threat is assessed to be medium. After considering the ratings for national combating ability and sectoral vunerablity, it can be concluded that the national vunerablity for money lanudering is assessed to be medium high, in which money laundering through banking activities are recorded at the highest risks among 15 potential risks in Vietnam. To contrast, regarding terrorism financing, Vietnam's risk assessment report on terrorist financing is assessed to be low and Vietnam's level of vulnerability to terrorist financing is low (Government of Vietnam, 2019).

The Anti-Money Laundering Department of the State Bank of Vietnam also firmed that particularly noted in the risk of money laundering is the banking sector with nearly $90 \%$ of the total number of suspicious transaction reports (Lam Giang, 2019). Looking at the recent money laundering investigations and it can be seen that the risk of money laundering in the banking sector may be primarily related to money laundering originating from property embezzlement, a major crime related to persons with positions, powers and crimes of gambling and tax evasion (Viet, 2019). Accordingly, to hide the sources of money collected, criminals often use bank accounts under other people's names to receive and transfer money of illegal origins (T.An, 2018). In addition, real estate is the field that attracts a lot of high-value investment money, real estate transactions can be made in cash or bank transfer and not through the exchange (Lam Giang, 2019). The real estate market makes it very difficult for the authorities to check and identify the source of money (Minh Son, 2019). Furthermore, the corruption cases of past time as well as the trillions of gambling cases have been investigated for money laundering, among the assets obtained from the cases are related to the properties as real estate and even, to launder money, offenders often ask family members to buy, transfer or donate real estate (Chat, 2013b).

Locations of money laundering offenders in the territory of Vietnam have also been surveyed. According to criminal statistics from 2010-2018 provinces across the country only a number of provinces and cities such as Hanoi, Ho Chi Minh City, and Hai Phong, trials on money laundering (Minh Son, 2019; T.An, 2018). Thus, money laundering only occurs in a number of provinces and cities with developed economic conditions and high population living standards (Lam Giang, 2019; State Bank of Vietnam, 2018). It is a place with favorable conditions, such as having many large banks and easily investing in real estate; for example offenders often buy land and garden houses in provinces with large areas such as Hoa Binh, Vinh Phuc, and Binh Duong or developed 
post and telecommunication service, provinces sharing the same border (Minh Son, 2019). Money laundering beyond national borders has become a serious international problem. Currently, according to the World Bank's assessment of developing countries such as Vietnam, which are considered as the target of criminal and illegal business organizations in the world due to Vietnamese law on money laundering crime, but specific in the banking industry, not specific and clear (Government of Vietnam, 2019). Facing the trend of world economic integration, banking activities are not only under economic pressure but also under increasing pressure from criminals related to banking activities because in addition to dealing with the Vietnamese banking system is now facing the risk of international criminal organizations coming to Vietnam as a place to launder money of illegal activities such as arms trafficking, drug trafficking, gambling or high-tech crime through the theft of data information to request money transfer to a personal account then withdraw money (State Bank of Vietnam, 2018). Along with the economic growth momentum, it is also the time when foreign FDI inflows into our country are increasing day by day, amounting to hundreds of millions of dollars for Vietnam to lend to Vietnam to build or implement development projects (Minh Son, 2019; T.An, 2018). In recent times, money laundering activities continue to be more and more sophisticated and diversified in many areas of social life. Besides affecting the financial system, money laundering also has a direct negative impact on the growth of the formal economic sector, in which it will divert and allocate resources in the inefficient formal sector (Chat, 2013b, 2014b). These investments not only create little economic efficiency but deviate from the natural supply and demand of the formal sector (Minh Son, 2019; T.An, 2018). Often in the real estate sector, art activities, antiques, jewellery and expensive auto industries are of interest to money launderers. Unusual signs of supply or demand in society are often caused by illicit actions and money laundering is a rare activity that creates imbalance in society (T.An, 2018; Viet, 2019).

According to State Bank of Vietnam (2018), although not all illicit proceeds are put into the money laundering crime, but compared to other sectors of the economy, the criminal's ability to choose the banking system to legalizing illicit revenues to turn those 'dirty money' into 'clean money' is higher. Although the 2015 Penal Code amended in 2017 came into effect in 2019, the results of investigations, prosecutions, and trials of money laundering are still very modest. Meanwhile, the risk of money laundering for embezzlement is very high. According to State Bank of Vietnam (2018) in the structure of corruption crimes, the number of cases and defendants who are tried every year for abuse of position, the right to appropriate property is very large but the amount of judgment enforced this type of crime accounts for a small proportion in the structure of criminal crimes. Through the cases of embezzled property, it can be seen that the amount of appropriated money is very large, there are cases that amount to hundreds of billions, even thousands of billion. The appropriated funds are used for personal expenses, real estate purchases, valuable assets or money laundering (Lam Giang, 2019).

\section{Legislative System to Combat Money Laundering in Vietnam}

Each country has different regulations on prevention of money laundering and international cooperation in prevention of money laundering. Vietnam defines the prevention and combat of money laundering as the responsibility of the Party-State, in which the State encourages domestic and foreign organizations and individuals to participate in, cooperate and sponsor money laundering prevention (Chat, 2013b, 2014b). Thanks to the awareness of the great risks and dangers, the problem of money laundering affects the financial-banking system in particular and the whole economy in general, for many years, the authorities such as the Ministry of Public Security, the State Bank of Vietnam, the Ministry of Justice, the Ministry of Finance have stepped in strongly and obtained positive results (Government of Vietnam, 2019). Accordingly, Vietnam has gradually consolidated the state agencies responsible for the prevention of money laundering such as to establish the steering committee for prevention of money laundering; to strengthen a specialized unit anti-money laundering department; to create focal points of ministries and agencies responsible for the prevention of money laundering, terrorism financing (State Bank of Vietnam, 2018).

On $7^{\text {th }}$ June 2005, the Government issued Decree No.74/2005/ND-CP on prevention of money laundering as the first legal document that introduces the concept of money laundering and measures to prevent and combat money laundering and is the legal basis for Vietnam to implement relevant international treaties to which Vietnam is a member. According to this Decree, the State Bank of Vietnam plays the leading role and coordinates with the Ministry of Public Security and relevant agencies to develop and implement strategies, guidelines, policies and plans for prevention, combat and prevention. money laundering in the territory of Vietnam. The Ministry of Public Security shall assume the prime responsibility and coordinate with the concerned agencies, organizations and individuals in the fight against crime related to money laundering. The State Bank of Vietnam established the AntiMoney Laundering Department as a national center in collecting, processing and transferring information related to money laundering. It can be said that the Decree No. 74/2005/ND-CP was born to meet the requirements of managing money laundering prevention and control activities in Vietnam, contributing to the transparency of the national finance. Implementing Decree No.74/2005/ND-CP, the State Bank issued Circular No.22/2009/TTNHNN of $17^{\text {th }}$ November 2009, guiding the implementation of measures to prevent and combat money laundering; the Ministry of Finance issued Circular No. 148/2010/TT-BTC dated $24^{\text {th }}$ September 2010, guiding the 
implementation of measures to prevent and combat money laundering in the field of insurance, securities and entertainment games with prizes; the Ministry of Construction issued Circular No.12/2011/TT-BXD dated $1^{\text {st }}$ September 2011, guiding the implementation of some contents of the Government's Decree No.74/2005/ND-CP on prevention of money laundering for real estate business activities.

Vietnam has a comprehensive legal framework for the prevention of money laundering, fighting against terrorist financing and was recognized by the Financial Task Force on money laundering (FATF) at the FATF Plenary Meeting in February 2014 (State Bank of Vietnam, 2018). In addition, the system of agencies and organizations responsible for the prevention of money laundering in Vietnam has been gradually strengthened and developed. Directly directing the prevention of money laundering in Vietnam is a National Steering Committee on money laundering prevention, which was established in 2009 and the current Head is Deputy Prime Minister (Chat, 2013a). The director is the leader of the concerned ministries and branches, the State Bank of Vietnam is the standing body of the Steering Committee. With the role of national coordinator on the prevention of money laundering, the Steering Committee promptly issued many documents directing the implementation of the prevention of money laundering and terrorism financing in Vietnam (Chat, 2013a). Since its establishment, the Steering Committee has issued four national action plans on prevention of money laundering and terrorism financing to address and overcome gaps in Vietnam's money laundering prevention and control mechanisms (Chat, 2014b).

According to experts, besides the positive changes in the enforcement of the law on prevention of money laundering in Vietnam, the reality of implementing the law on prevention of money laundering also has some issues that need to be continued research and adjustment, especially the completion of the relevant legal corridor (Chat, 2013a, 2014a). Currently, there are a number of areas with potential risks of money laundering but not yet specified in the law. Some active entities may be abused for money laundering but have not been regulated in the reporting subjects. In addition, some provisions of the Law on money laundering prevention are not synchronized and overlapping, leading to inadequacies in the implementation process (Chat, 2013b). There are still some unclear and specific regulations, so guidance is needed to ensure uniform application of the law in adjudication and to meet the new international standards on money laundering prevention (Khoa \& Phuc, 2012). Many regulations have not been concretized and inappropriate, so they have not promoted the capacity and authority of law enforcement agencies, causing criminals to wriggle the Law on money laundering prevention in Vietnam (Chat, 2013b). In fact, prevention of money laundering in Vietnam still faces many difficulties due to subjective and objective reasons, while the theory of this crime prevention and control has not yet been approved proper mind. International cooperation in the prevention of money laundering has been carried out in both bilateral and multilateral aspects, however, the cooperation process still revealed certain limitations and shortcomings (Chat, 2013b, 2014a; State Bank of Vietnam, 2018).

\section{International cooperation in the prevention of money laundering in Vietnam}

With the proactive and active policy of international economic integration, Vietnam's bilateral, regional and global economic relations with other countries and international organizations are increasingly expanded. Vietnam is currently a member of the United Nations, World Trade Organization, Association of Southeast Asian Nations (ASEAN), Asia-Europe Cooperation Forum (ASEM), Asia-Pacific Economic Cooperation Forum (APEC), World Bank, International Monetary Fund, Asian Development Bank and many other international and regional organizations. Vietnam's economic cooperation with major economies like the United States, EU, Japan, Russia, China, India, etc. has been increasingly strengthened and expanded (Australian Government, 2018). Vietnam has also ratified many bilateral and multilateral Free Trade Agreements (FTAs) with regional and world partners. So far, Vietnam has established diplomatic relations with 185 countries, promoting economic, trade and investment relations with 224 markets in all continents (Government of Vietnam, 2018).

International cooperation in this global economic era is an indispensable trend in the development process of each country in the process of mobilization and transformation of the world so that countries can support each other in solving problems international issues, interacting with each other (Australian Government, 2018; Government of Vietnam, 2018). Recognizing the importance of prevention and combat of money laundering, combating financing for terrorism, Vietnam has made efforts to deploy more and more effectively the mechanism of prevention of money laundering and combating terrorist financing through the promulgation and effective implementation of legal documents in this field (Government of Vietnam, 2019). Accordingly, along with the efforts of the Government and ministries, sectors, in recent years, international cooperation activities on money laundering prevention and fighting continue to be promoted in both width and depth, making a positive contribution to the implementation. effective prevention of money laundering of Vietnam.

Regarding anti-money laundering, Vietnam is also active in joining international organizations in the field of money laundering. In parallel with domestic money laundering prevention activities, Vietnam has gradually taken initiative in international integration in this field, marked by Vietnam's accession to and becoming the 34th member of the Asia-Thai Group. Binh Duong on anti-money laundering (APG) in May 2007 (Chat, 2014b). As a member 
of APG, Vietnam has committed to comply with the provisions of the "APG Terms of Reference", namely 1) to take necessary actions to combat money laundering and terrorist financing; 2) to take active, proactive steps to develop, adopt and enforce laws and other measures against money laundering and counter-terrorism financing based on internationally recognized standards; 3 ) to recognize the benefits of sharing information and experiences; and 4) to commit to enforce APG decisions. As a member of APG, Vietnam is responsible for complying with FATF recommendations and fulfilling its membership obligations (Chat, 2014a, 2014b). In 2008, Vietnam underwent a multilateral assessment of its anti-money laundering and terrorist financing mechanism under 40+9 FATF Recommendations. Vietnam is currently an observer of the Egmont Financial Intelligence Group and is in the process of applying for membership.

Regarding information exchange to prevent of money laundering and terrorism financing with Financial Intelligence Units (FIUs), the State Bank of Vietnam has signed nine Memorandum of Understanding (MOU) to exchange information related to money laundering and terrorist financing with other countries and is in the process of negotiating to sign MOU with other countries around the world (Chat, 2014a, 2014b). In addition, the State Bank of Vietnam and other authorities have also stepped up a number of other cooperative activities such as ratification, participation and implementation of international conventions and protocols with contents related to prevention and control money laundering, countering terrorist financing. Besides, Vietnam signed and joined bilateral treaties and treaties on crime prevention in general (the source crime of money laundering) and prevention of money laundering crime and terrorist financing in particular as well as actively researched the process of joining international organizations, informal information sharing channel on prevention of money laundering and financing of terrorism and other crimes (Lam Giang, 2019). Furthermore, Vietnam cooperated in the field of judicial assistance in extradition, investigation, prosecution, and trial of money laundering offenses and the precursor offenses of money laundering, terrorism and terrorism financing (State Bank of Vietnam, 2018).

As an active and responsible member of the international community and the United Nations, Vietnam has signed and acceded to many international and regional treaties on anti-crime in general and anti-money laundering and financing terrorist in particular. Specifically, Vietnam signed and acceded to the United Nations Conventions on Money Laundering and Countering Terrorist Financing, including the 2000 Transnational Organized Crime Convention (Paris Convention ); Convention on combating the illegal trade of narcotics and psychotropic substances in 1988 (Vienna Convention), the Convention on Punishment of Terrorist Financing, 1999, the AntiCorruption Convention 2005 (Merida Convention), ASEAN Convention on Counter-Terrorism 2007, Protocol on the Prevention, Punishment, and Suppression of Trafficking in Persons, Especially Women and Children, 2000 (Chat, 2014a, 2014b). In addition, Vietnam is an observer at the United Nations Crime Prevention and Criminal Justice Committee (CCPCJ) under the United Nations Economic and Social Council. Every year, Vietnam sends delegates to the Commission's meeting in Vienna, the Republic of Austria through this forum to outline Vietnam's achievements in the prevention of transnational organized crime, especially terrorist crime; implementation of the United Nations Convention against Transnational Organized Crime (UNTOC) and the United Nations Convention against Corruption (UNCAC); demonstrating Vietnam's views on international community issues as well as Vietnam's concerns; at the same time, exchange and learn experiences to improve the legal system on crime prevention and criminal justice (Chat, 2014a, 2014b).

With the above results, it is possible to see the continuous efforts and determination of the National Assembly and the Government of Vietnam in coordinating with APG, FATF, countries and international organizations in the fight against money laundering and counter terrorism financing, contributing to ensuring the transparency and integrity of the world financial system.

\section{Some solutions to improve the effectiveness of international cooperation in the prevention of money laundering}

Firstly, to advise the government and competent agencies to promulgate legal documents and guiding documents related to money laundering prevention.

Vietnam now avoids the risk of being put on the list of countries at risk of money laundering and terrorism financing by the international financial task force FATF, which destabilizes the international financial system. However, according to the agency's assessment, Vietnam is still on the list of countries with a shortage of antimoney laundering and anti-terrorism mechanisms. Therefore, in the coming time, based on the achieved results, Vietnam needs to comply with FATF's proper requirements to avoid the risk of damaging the reputation and foreign trade activities. The specific tasks to be implemented include: First, to ensure the development and issuance of documents related to the prevention of money laundering. Second, supplement guidance to identify suspicious transactions, even for those transactions intended to be performed or not yet completed but in nature. Third, maintain and strengthen measures to put the policy of a cashless economy into practice, promote electronic payment in e-commerce. Fourth, strengthening the capacity of the anti-money laundering forces to become a real focal point in collecting, sharing and processing information of the reporting subjects according to the Law on money laundering prevention and combat. 
Secondly, promoting research, building theories about money laundering crimes and good propaganda on money laundering prevention.

In order to raise the awareness of money laundering criminals, it is necessary first to have a relatively complete theoretical system suitable to the reality of the criminal situation in Vietnam. Because units need to step up theoretical research, inherit the scientific achievements of crimes and investigate criminals of leading countries with high professional skills in preventing and combating money laundering crimes such as the U.K., U.S., and Russia. Besides, the research, summarizing the reality of fighting against crime in Vietnam also need to be focused. Although the fight against money laundering crime in Vietnam is still not effective, but with achievements in the prevention and fight against other types of crimes, especially economic and drug crimes, these are strengths. for reference to manipulate.

Thirdly, diversify international cooperation mechanisms, improve the capacity of law enforcement officers in the field of money laundering prevention.

In the context of the country's deep and wide integration with the region and the world, besides the advantages of an increase in the number and type of crime, the training of international cooperation officials in prevention and combat of washing Money will have to focus on important issues such as training police in the direction of multidisciplinary and multidisciplinary at university and postgraduate level; innovating methods of organizing and managing police training; innovating teaching and coaching methods, changing teaching methods to maximize the creativity and self-study capacity of learners, not only learning theory but combining theory with practice, improving skills performance. In addition, attention should be paid to the exchange and sharing of police training experience of nations, effectively exploiting the knowledge and experience of international friends, raising the level of officers and soldiers.

Accordingly, annual training and retraining of full-time or part-time officials and employees in prevention and combat of money laundering in the prevention and combat of money laundering in foreign languages and professional skills. The content of training and retraining in professional of prevention and combat of money laundering must include at least: legal provisions and internal regulations on prevention of money laundering; legal responsibilities when not implementing the provisions of the law on prevention of money laundering; methods and tricks of money laundering; money laundering risks related to products, services and tasks that officials and employees are assigned to perform.

Fourthly, perfect the organization, coordinate and direct effectively in international cooperation for the prevention of money laundering.

Over the past years, law enforcement agencies, Procuracy, Court and the State Bank have actively implemented the task of preventing and combating money laundering through professional measures of their sector. In addition, the parties have coordinated in exchanging information on money laundering, the situation, money laundering trends, alerting new tricks of the crime, legal regulations and coordinating the implementation of preventive measures. preventing and preventing money laundering, appointing full-time officials to participate in thematic reports at conferences on money laundering prevention and control organized by the parties. Units shall have to guide the State Bank's branches, police forces, procuracies and courts in provinces and cities to formulate coordination regulations to suit the specific situation in their localities. Exchanging and coordinating professional work through official documents, or by means of communication, through officials assigned to the focal point of operations, sending officials to directly participate in coordinating plans and tasks specific circumstances of each party. Every year, the parties organize a briefing to review the situation, the results of coordination in money laundering prevention, and propose specific measures and action coordination programs in the next period based on department of content on coordination regulations in the prevention of money laundering crime.

In order for the coordination regulations to be effective, the parties need to coordinate and direct their attached units to implement synchronously and effectively the signed coordination regulations. Continuing to concretize the contents, forms, mechanisms of coordination among the parties with annual action programs, specific professional plans and specialized projects; regularly and timely exchange information on the situation of money laundering crime; coordinate in organizing training and fostering to raise the capacity and qualifications of officials directly involved in the fight against crime in general and money laundering in particular, contributing to maintaining political security and social order.

In the appropriate case, it is necessary to determine the role of the police force and the State Bank with the role of focal point will closely, regularly, provide timely information to the relevant units about the crime situation. Furthermore, they propagandize, guide, train and train officials of units to raise awareness and awareness of officials related to this field. Officials of ministries and branches should coordinate in formulating long-term and annual plans on signing, joining and implementing international treaties on the prevention and combat of money laundering crimes, in coordination to review laws on criminal justice assistance. Moreover, the activities of negotiating international treaties on criminal justice assistance, extradition and transfer of imprisonment debtors must involve the concerned ministries and branches. In particular, interdisciplinary coordination has always been effective in addressing specific support requests that have been encountered. 
In addition to the above-mentioned contents, the Ministry of Public Security should closely coordinate with the Supreme People's Procuracy and the Supreme People's Court in well performing advisory work for the State and the Government and directly performing its duties. the case of expanding international cooperation in the prevention and combat of money laundering offenses, first of all with neighboring countries, countries with traditional relations and countries in ASEAN region. Organize the good implementation of international conventions, mutual legal assistance agreements, anti-crime cooperation cooperation agreements which our State has signed or acceded to. Continue to study on joining and signing other international treaties related to crime prevention.

Fifthly, take the initiative in coordinating measures to prevent, detect and investigate source crimes, focusing on cross-border money laundering crime.

Money laundering criminals have their causes and conditions from socio-economic issues themselves. Therefore, to prevent money laundering offenses must first start with socio-economic measures. By promoting the development of the economy, people's lives will be improved, when the economic potential is improved, it is inevitable that it can solve social policy issues, labor and employment issues. made for everyone. Solving pressing social issues, creating jobs for a large number of workers (including those who have criminal records, giving them a stable life) is of great significance in crime prevention. money laundering.

Along with economic development measures, social issues also need to be focused on solving. It is necessary to focus on measures to address pressing social issues that also have the effect of preventing and eliminating the causes and conditions of crimes in general and money laundering in particular. Promoting the strength of the entire population and all branches and levels in the fight against social evils and solving social problems is the basis for more effective crime prevention.

In addition, criminal organizations often take full advantage of the loopholes of the laws of countries to commit crimes with the lowest level of risk. Western countries' strengthening anti-money laundering measures have forced criminals to transfer money laundering activities to other countries, such as depositing money in banks in countries where the law does not require identifying sources. Principal or not limited to the value of cash transactions. Therefore, the improvement of the legal system of countries is an urgent requirement today. Some countries have established a mechanism to automatically declare all cash transactions from a certain value or more. Finally, some countries have enacted laws that regulate the ability to use controlled transportation techniques for funds of illegal origin. These laws allow the investigating authority to control bank accounts, receive information related to banking secrets provided by banking or financial authorities. In addition, confiscation of money and property acquired through the commission of an offense is an indispensable continuation of the repressive measures of money laundering.

To re-state that facing to real situation and serious consequences caused by money laundering crimes has been continuing to impact negatively on the fields of economy, culture, society, security and defense. Up to now, the criminal situation has had many positive changes, the fight against money laundering crime has achieved remarkable results, contributing to curbing crimes and social evils, including positive contribution of international cooperation in the prevention and combat of money laundering crime. In the context of the situation of crime in the region still complicated, international cooperation to combat money laundering is an unavoidable measure to improve the effectiveness to ensure the transparency of financial flows among countries around the world.

\section{Reference}

Australian Government. (2018, 28 February 2018). Vietnam Country Brief. Retrieved from https://dfat.gov.au/geo/vietnam/Pages/vietnam-country-brief.aspx

Borlini, L. (2014). The Economics of Money Laundering. In P. Reichel \& J. S. Albanese (Eds.), Handbook of Transnational Crime and Justice (2nd ed., pp. 227-243). London: Sage.

Chat, L. N. (2013a). Criminalisation of Money Laundering in the International Anti-Money Laundering Regime and its Adoption by Vietnam. Australian Journal of Asian Law, 14(1), 1-17.

Chat, L. N. (2013b). The Growing Threat of Money Laundering to Vietnam: The Necessary of Intensive Countermeasures. Journal of Money Laundering Control, 16(4), 321-332.

Chat, L. N. (2014a). The International Anti-Money Laundering Regime and Its Adoption by Vietnam. Asian Journal of International Law, 4(1), 197-225.

Chat, L. N. (2014b). International Anti-Money Laundering Standards and Their Implementation by Vietnam. (PhD Law). University of Canterbury, Canterbury. Retrieved from https://ir.canterbury.ac.nz/bitstream/handle/10092/9827/thesis fulltext.pdf?sequence=1\&isAllowed=y

Chat, L. N. (2020). National Criminal Jurisdiction over Transnational Financial Crimes. Journal of Financial Crime doi:10.1108/JFC-09-2019-0117

Croissant, A., \& Barlow, D. (2007). Following the Money Trail: Terrorist Financing and Government Responses in Southeast Asia. Studies in Conflict \& Terrorism, 30(2), 131-156. doi:10.1080/10576100600959721

FATF. (2010a). Global Money Laundering and Terrorist Financing Threat Assessment. Retrieved from Paris, 


\section{France:}

FATF. (2010b). An Introduction to the FATF and Its Work [Press release]. Retrieved from https://www.fatfgafi.org/media/fatf/documents/brochuresannualreports/Introduction $\% 20$ to $\% 20$ the $\% 20$ FATF.pdf

Global Financial Integrity. (2017). Transnational Crime and the Developing World. Retrieved from Washington D.C.:

Global Financial Integrity. (2019). Illicit Financial Flows to and from 148 Developing Countries: $2006-2015$. Retrieved from Washington D.C.: https://secureservercdn.net/45.40.149.159/34n.8bd.myftpupload.com/wpcontent/uploads/2019/01/IFF-Report-2019_11.18.19.pdf?time $=1585196035$

Government of Vietnam. (2018). Vietnam's Voluntary National Review on the Implementation of the Sustainable Development Goals. Retrieved from Hanoi, Vietnam:

Vietnam-National Risk Assessment on Money Laundering and Terrorism Financing 2012-2017, (2019).

Hutley-Washington, M. (2018) Investigate Practices for Large Money Laundering Crimes. In: Vol. 26. Economic Crime Forensics Program. Capstone: La Salle University.

Khoa, D. C., \& Phuc, D. (2012). Applying Data Mining in Money Laundering Detection for the Vietnamese Banking Industry. In J.-S. Pan, S.-M. Chen, \& N. T. Nguyen (Eds.), Intelligent Information and Database Systems (4th Asian Conference, ACIIDS 2012, Kaohsiung, Taiwan, March 19-21, 2012, Proceedings, Part II) (pp. 207-216). Singapore: Springer.

Kruisbergen, E., Leukfeldt, R., Kleemans, E., \& Roks, R. (2019). Money Talks Money Laundering Choices of Organized Crime Offenders in a Digital Age. Journal of Crime and Justice, 42(5), 569-581. doi:10.1080/0735648X.2019.1692420

Kubiciel, M. (2012). International Legal Development and National Legal Change in the Fight Against Corruption'. In D. Linna (Ed.), Legitimacy, Legal Development and Change: Law and Modernization Reconsidered (pp. 419-436). London: Routledge.

Lam Giang. (2019). Chong rua tien va tai tro khung bo: 90\% giao dich dang ngo di qua ngan hang [trans: Combating Money Laundering and Terrorism's Financial Funding: 90\% Suspicious Transactions through Banking]. 16 August. Retrieved from http://vneconomy.vn/chong-rua-tien-va-tai-tro-khung-bo-90-giao-dichdang-ngo-di-qua-ngan-hang-20190816053313864.htm

Levi, M. (2002). Money Laundering and Its Regulation. Annals of the American Academy of Political and Social Science, 582(Cross-National Drug Policy), 181-194.

Lilley, P. (2003). Dirty Dealing: The Untold Truth about Global Money Laundering, International Crime and Terrorism. London: Kogan Page.

Minh Son. (2019). 90 Percent of Suspected Money Laundering in Vietnam Done Through Banks. 21 May. Retrieved from https://e.vnexpress.net/news/business/economy/90-percent-of-suspected-money-launderingin-vietnam-done-through-banks-3926258.html

Reuter, P., \& Truman, E. (2004). Chasing Dirty Money: The Fight Against Money Laundering. Washington D.C.: Peterson Institute.

Schneider, F. (2008). Money laundering and financial means of organised crime: some preliminary empirical findings. Retrieved from Milan, Italy:

Schneider, F. (2010). Money Laundering and Financial Means of Organized Crime: Some Preliminary Empirical Findings. Retrieved from Berlin, Germany:

Shehu, A. Y. (2000). Money Laundering: the Challenge of Global Enforcement. Paper presented at the a seminar of the Criminology Society of Hong Kong.

Stankiewicz, N. (2015). Using Anti-Money Laundering Measures in the Financial World to Combat Organized Crime. Inquires Journal, 7(10). Retrieved from http://www.inquiriesjournal.com/articles/1268/2/using-antimoney-laundering-measures-in-the-financial-world-to-combat-organized-crime

State Bank of Vietnam. (2006). Giai phap va kinh nghiem phong chong rua tien qua ngan hang [trans: Solutions and Experiences to Combat Money Laundering through Banking]. 9 February. Retrieved from https://www.sbv.gov.vn/webcenter/portal/vi/menu/fm/ddnhnn/nctd/nctd chitiet?leftWidth=20\%25\&showFo oter $=$ false \&showHeader $=$ false $\&$ dDocName $=$ CNTHWEBAP01162524501\&rightWidth $=0 \% 25 \&$ centerWidt $\mathrm{h}=80 \% 25 \&$ afrLoop $=1717793134176852 \# \% 40 \% 3 \mathrm{~F}$ afrLoop $\% 3 \mathrm{D} 1717793134176852 \% 26$ centerWidth $\% 3$ D80\%2525\%26dDocName\%3DCNTHWEBAP01162524501\%26leftWidth\%3D20\%2525\%26rightWidth\% 3D0\%2525\%26showFooter\%3Dfalse\%26showHeader\%3Dfalse\%26 adf.ctrl-state\%3D12z7mqy0i9 9

State Bank of Vietnam. (2018). Hoi thao danh gia rui ro quoc gia ve rua tien va tai tro khung bo [trans: Assessment Workshop on National Risks in Money Laundering and Terrorism Financing]. 27 June. Retrieved from https://www.sbv.gov.vn/webcenter/portal/vi/menu/fm/pcrt/ttpcrt/ttpcrt_chitiet?leftWidth=20\%25\&showFoot er $=$ false $\&$ showHeader $=$ false $\& \mathrm{dDocName}=\mathrm{SBV} 343203 \&$ rightWidth $=0 \% 25 \&$ centerWidth $=80 \% 25 \&$ afrLo $\mathrm{op}=1718717821953852 \# \% 40 \% 3 \mathrm{~F}$ afrLoop $\% 3 \mathrm{D} 1718717821953852 \% 26$ centerWidth $\% 3 \mathrm{D} 80 \% 2525 \% 26 \mathrm{dD}$ ocName\%3DSBV343203\%26leftWidth\%3D20\%2525\%26rightWidth\%3D0\%2525\%26showFooter\%3Dfal se\%26showHeader\%3Dfalse\%26_adf.ctrl-state\%3D12z7mqy0i9_135 
T.An. (2018). Cac thu doan rua tien o Viet Nam rat tinh vi [trans: Methods of Money Laundering in Vietnam is Very Sophisticated]. 9 July. Retrieved from https://plo.vn/phap-luat/cac-thu-doan-rua-tien-o-viet-nam-rattinh-vi-781091.html

Tang, J., \& Ai, L. (2010). Combating Money Laundering in Transition Countries: The Inherent Limitations and Practical Issues. Journal of Money Laundering Control, 13(3), 215-225. doi:10.1108/13685201011057127

UNODC. (2020). Money-Laundering and Globalization. Retrieved from https://www.unodc.org/unodc/en/moneylaundering/globalization.html

Viet, Q. V. (2019). Nhan xet ve bao cao rua tien o Viet Nam cua To chuc Liem chinh Tai chinh toan cau [trans: Assessments in the Money Laudering's Report of Vietnam by the Global Financial Integrity]. 14 October. Retrieved from https://rithucvn.net/blog/nhan-xet-ve-bao-cao-rua-tien-o-viet-nam-cua-to-chuc-liem-chinhtai-chinh-toan-cau.html

Williams, P. (2001). Crime, Illicit Markets, and Money Laundering. In P. J. Simmons \& C. Ouderen (Eds.), Challenges in International Governance (pp. 106-150). Washington D.C.: Carnegie Endowment for International Peace. 